\title{
Nutrient effects on intertidal community: from bacteria to invertebrates
}

\author{
J. M. Y. Chiu, R. Zhang, H. Wang, V. Thiyagarajan, P. Y. Qian* \\ Department of Biology/Coastal Marine Laboratory, The Hong Kong University of Science and Technology, Clearwater Bay, \\ Kowloon, Hong Kong, SAR
}

\begin{abstract}
This study investigated the impacts of nutrient enrichment on intertidal biofilm microbial communities and on larval metamorphosis of invertebrates. We modulated the nutrient levels in the water column during biofilm development and examined the resulting biofilms for bacterial and diatom community composition using 2 DNA fingerprinting techniques and microscopic examination, respectively. Results of both terminal-restriction fragment length polymorphism (T-RFLP) and denaturing gradient gel electrophoresis (DGGE) analyses indicated that the nutrient enrichment treatment altered the biofilm bacterial communities relative to the control. Biofilms that had different microbial compositions were tested for their effects on larval metamorphosis of the polychaete Hydroides elegans, the barnacle Balanus amphitrite, and the slipper limpet Crepidula onyx. We showed that nutrient enrichment in the water column effectively changed the biofilm composition in ways that increased its inductiveness for larval metamorphosis of $C$. onyx and $B$. amphitrite, but not of $H$. elegans. This study highlights the apparent importance of nutrient enrichment in influencing the intertidal biofilm composition directly and the invertebrates indirectly.
\end{abstract}

KEY WORDS: Bacteria $\cdot$ Biofilms $\cdot$ Larvae $\cdot$ Nutrients

\section{INTRODUCTION}

The world's coastal and estuarine waters are becoming more eutrophic due to the influences of everincreasing anthropogenic activities (reviewed by Worm et al. 2000). Sewage discharge, use of agricultural fertilizers, freshwater runoff, and coastline construction greatly increase the transfer of nutrients to coastal areas. Over the past decade or so, there has been a growing interest in the investigation of the effects of nutrient enrichment on nearshore ecosystems. Previous studies have collectively suggested that an increase in nutrient levels could cause changes in the composition and functioning of marine communities (e.g. Minchinton \& Bertness 2003, Morris \& Keough 2003). Of particular note, the impacts of nutrient enrichment on benthic systems are largely undocumented.

Substratum preference for larval metamorphosis (e.g. Toonen \& Pawlik 1994) may govern the popula- tion dynamics of marine benthic communities. Barnacle, polychaete, bryozoan, oyster, and gastropod larvae have been reported to metamorphose in response to biofilms of different ages and origins (reviewed by Wieczorek \& Todd 1998). Biofilms may vary in space and time in terms of species composition, physical attributes, and physiological activity. Such variations are primarily attributed to prevailing biotic factors such as the availability, diversity, and physiology of colonizing species, and abiotic factors including latitude, depth, illumination, exposure time, season, water chemistry, flow shear, and substratum physical characteristics (reviewed by Wieczorek \& Todd 1998).

Previous studies have shown that nutrient levels in the water column can affect the larval metamorphosis of invertebrates including the blue crab Callinectes sapidus (Forward et al. 1997), the oysters Crassostrea virginica and Crassostrea gigas (Fitt \& Coon 1992), and the coral Diploria strigosa (Bassim \& Sammarco 2003). 
Although some attention has been paid to the direct inductive effects of nutrient enrichment on larval metamorphosis (e.g. Fitt \& Coon 1992), there may be indirect effects of nutrient enrichment through biofilms. Whether nutrient enrichment is effective in changing the biofilm composition in ways that alter its effects on larval metamorphosis remains unknown. Furthermore, it was demonstrated that nutrient enrichment could cause changes in the composition of intertidal communities even though the mechanisms underlying those changes were not understood (e.g. Morris $\&$ Keough 2003). Therefore, our objective was to investigate the role of nutrients on biofilms, and consequently on the metamorphosis of invertebrate larvae, which affects the recruitment process and hence the composition of intertidal communities.

In this study, we developed biofilms in the field under nutrient enrichment and control conditions; the nutrient levels in the water column were modulated by using a fertilizer which releases a cocktail of nutrients that are representative of those being transferred to coastal areas (Morris \& Keough 2003). Because of the importance of bacteria and diatoms on larval metamorphosis (e.g. Qian et al. 2003, Lau et al. 2005, Chiu et al. 2007), resulting biofilms were examined for diatom and bacterial cell densities and community composition. Then we tested the effects of the biofilms on larval metamorphosis of the polychaete Hydroides elegans, the barnacle Balanus amphitrite, and the slipper limpet Crepidula onyx. Biofilms are one of the key natural inductive cues for the larval metamorphosis of H. elegans, B. amphitrite, and C. onyx (e.g. Miron et al. 1999, Shikuma \& Hadfield 2005, Chiu et al. 2007). These species are excellent model organisms to examine the relationships between environmental factors, biofilms, and larval metamorphosis (e.g. Lau et al. 2005, Chiu et al. 2007). Furthermore, they are commonly found in the intertidal zone on rocky shorelines in Hong Kong which are under the influence of sewage discharge (Lau et al. 2005, Chiu et al. 2007).

\section{MATERIALS AND METHODS}

Developing biofilms in the field. Biofilms were allowed to develop for $10 \mathrm{~d}$ on polystyrene Petri dishes (FALCON no. 1006) mounted on plastic frames $(50 \mathrm{~cm}$ length $\times 55 \mathrm{~cm}$ width) which were deployed at the low intertidal zone at Port Shelter, Hong Kong $\left(22^{\circ} 19^{\prime}\right.$ N, $\left.114^{\circ} 16^{\prime} \mathrm{E}\right)$. Port Shelter was exempt from nitrogen inputs from the Pearl River and sewage discharge to other locations such as Victoria Harbour of Hong Kong waters (reviewed by Lee et al. 2006). The response of biofilms receiving nutrient enrichment may vary considerably depending on prevailing environmental con- ditions. If the waters are eutrophic, there may be no response to the nutrient enrichment treatment (Morris $\&$ Keough 2003). The present study was conducted in summer 2007, when salinity was 30 to 32 psu and seawater temperature was about $29^{\circ} \mathrm{C}$. There were 2 replicate frames for nutrient enrichment and control treatments, which were placed intermittently. Each replicate frame had 20 Petri dishes; not all dishes were used for biofilm analysis or larval metamorphosis bioassays. These frames were carefully arranged so that they had the same depth, and most likely, illumination, exposure time, and water flow. We used Osmocote ${ }^{\circledR}$ Smart-Release ${ }^{\circledR}$ Plant Food (Scotts-Sierra Horticultural Products), which provides $16 \% \mathrm{~N}\left(\mathrm{NH}_{4}\right.$ and $\left.\mathrm{NO}_{3}\right), 5 \% \mathrm{P}\left(\mathrm{P}_{2} \mathrm{O}_{5}\right)$, and $15 \% \mathrm{~K}_{2} \mathrm{O}$ for nutrient enrichment (Worm et al. 2000). The fertilizer granules coated with semi-permeable resin coatings were applied using a diffuser bag of $2.5 \mathrm{~cm}$ length $\times 2.5 \mathrm{~cm}$ width made from nylon mesh (125 $\mu \mathrm{m}$ mesh size). Five diffuser bags each filled with $10 \mathrm{~g}$ of fertilizer were placed at the 4 corners and the center of the plastic frame in the enrichment treatment. The control treatment consisted of the same set-up without fertilizer fill. The frames were separated by at least $2 \mathrm{~m}$. We did not monitor the nutrient concentrations on the enrichment versus control treatments, yet any observed nutrient effects on the community were deemed the result of successful enrichment (reviewed by Worm et al. 2000). Furthermore, it has been reported that there was a steep spatial gradient in nutrient concentration in a reef study; at $1 \mathrm{~m}$ distance nutrients were diluted by $>1$ order of magnitude (reviewed by Worm et al. 2000).

At the end of the $10 \mathrm{~d}$ field period, the biofilmed dishes were collected and immediately transferred to the laboratory in autoclaved membrane-filtered (pore size $0.22 \mu \mathrm{m}$ ) seawater. Biofilmed dishes in 2 replicate frames from the same treatment were first pooled together. Biofilms were then analyzed for diatom and bacterial cell densities and community composition after the dishes were gently rinsed with autoclaved filtered seawater to remove planktonic cells and loose particles. The biofilmed dishes were also used to test for their ability to induce larval metamorphosis. For each biofilm analysis and larval metamorphosis bioassay, there were 5 replicate biofilmed dishes. Bacterial and diatom community composition in biofilms were determined using terminal-restriction fragment length polymorphism (T-RFLP) and denaturing gradient gel electrophoresis (DGGE) analyses, and microscopic examination, respectively. DNA was separately extracted and purified from each of the 5 replicate biofilmed dishes.

Enumeration of bacteria and diatoms and morphological analysis of diatom community composition. Biofilms were fixed with $4 \%(\mathrm{v} / \mathrm{v})$ formaldehyde in 
autoclaved filtered seawater. Diatoms in 5 haphazardly chosen non-overlapping fields of view on each biofilm were enumerated under direct light microscopy at a magnification of $400 \times$. Diatoms were classified into 11 genera or morphotypes using identification keys based primarily on those of Tomas (1996). The films were then stained for 15 min with 4,6-diamidino2-phenylindole (DAPI) at a concentration of $1 \mu \mathrm{g} \mathrm{ml}^{-1}$, and bacteria in 5 haphazardly chosen fields of view for each biofilm were enumerated using an epifluorescence microscope at a magnification of $1250 \times$.

Extraction of bacterial community DNA. To determine bacterial diversity, biofilms were scraped from Petri dish surfaces using sterile glass coverslips followed by brushing with nylon brushes. These treatments removed $>90 \%$ of the biofilm materials, as determined by microscopic examination of diatom and bacterial cell densities. The biofilms were then suspended in $0.8 \mathrm{ml}$ of lysis buffer. Total DNA was extracted and purified using standard phenol-chloroform method (Liu et al. 1997).

Terminal-restriction fragment length polymorphism analysis. The 16S rRNA genes in the DNA were amplified by polymerase chain reaction (PCR) using the Bacteria domain specific primer pair 341F (CCTACGGGAGGCAGCAG) and 907R (CCGTCAATTCCTTTRAGTTT) (Liu et al. 1997). The primer 907R carried a fluorescent label (Fam) at the 5' end. The size of the amplified DNA was verified and the amount was estimated by agarose electrophoresis. Fluorescently labeled PCR products were digested with $20 \mathrm{U}$ MspI (Boehringer Mannheim) at $37^{\circ} \mathrm{C}$ for $6 \mathrm{~h}$. The digested amplicons were purified with the Wizard ${ }^{\circledR}$ PCR prep DNA purification system (Promega). Aliquots of purified products were mixed with internal size standard ET-550 (Amersham) before capillary electrophoresis on a MegaBACE ${ }^{\circledR}$ genetic analyzer (Amersham) operating in Genotyping mode. After electrophoresis, the lengths of the fluorescently labeled terminal-restriction fragments (T-RFs) were determined by comparison with the internal standards, using a Genetic Profiler package (Amersham).

Denaturing gradient gel electrophoresis. The $16 \mathrm{~S}$ rRNA genes were amplified by PCR using the primer pair $341 \mathrm{~F}$ and $907 \mathrm{R}$ (Lau et al. 2005). The primer 341F carried a GC-clamp (CGCCCGGGGCGCGCCCCGGGCGGGGCGGGGGCACGGGGG) at the 5' end. DGGE of PCR products was performed in a DGGE1001 system (CBS Scientific). The PCR products were resolved in a $1 \mathrm{~mm}$ thick vertical gel containing $8 \%$ (w/v) polyacrylamide (37.5:1 acrylamide:biacrylamide) and a linear gradient of 40 to $80 \%$ chemical denaturants; $100 \%$ denaturants were $7 \mathrm{M}$ urea and $40 \%$ formamide. Electrophoresis (125 V for $18 \mathrm{~h}$ ) was performed in $1 \times$ Tris-acetate EDTA buffer maintained at $60^{\circ} \mathrm{C}$. DNA bands were subsequently visualized using
Sybr Gold stain (1:1000 dilution; Invitrogen) and photographed with UV transillumination (302 nm) using Alpha Imager 2000 (Alpha-Innotech).

The middle portion of each selected DGGE band was excised, washed, transferred to $50 \mu \mathrm{l}$ of Milli-Q water, and incubated at room temperature for $4 \mathrm{~h}$ before reamplification by PCR. Reamplified products were purified using a Wizard ${ }^{\circledR}$ PCR prep DNA purification system (Promega) and then sequenced directly from both ends or cloned using a TOPO TA Cloning Kit (Invitrogen). The size of the DNA insert was verified by PCR using the primers M13F (GTAAAACGACGGCCAG) and M13R (CAGGAAACAGCTATGAC) (Invitrogen). The DNA insert was then sequenced from both ends using the same primer set. Three clones of each band were sequenced. The 2 nucleotide sequences obtained for a clone/band were assembled using the Sequencer 4.2 (Gene Codes). Sequence homologies were determined using the BLAST search in GenBank.

Adult maintenance, larval culture, and bioassays of Crepidula onyx. Adults of Crepidula onyx were collected from the low intertidal zone in Victoria Harbour, Hong Kong $\left(22^{\circ} 17^{\prime}\right.$ N, $\left.114^{\circ} 10^{\prime} \mathrm{E}\right)$ and held in an aquarium on a diet of the naked flagellate Isochrysis galbana (Tahitian strain, clone T-ISO) in the Coastal Marine Laboratory at Hong Kong University of Science and Technology. Larvae released from these adults were reared in filtered seawater on a diet of $I$. galbana. The water was changed every other day. After 5 d, larval competence was assessed daily by checking the occurrence of shell 'brims' and by a $6 \mathrm{~h}$ bioassay using seawater whose $\mathrm{K}^{+}$concentration had been elevated by 15 mM (Pechenik \& Gee 1993). Petri dishes with biofilmed surfaces were used to test the effects of biofilms on metamorphosis of $C$. onyx larvae. Bioassays were carried out according to Pechenik et al. (2002). Briefly, 10 larvae were pipetted into each dish containing biofilms with $10 \mathrm{ml}$ autoclaved filtered seawater and incubated in still water. Autoclaved filtered seawater in a clean Petri dish served as the negative control. The positive control consisted of seawater with a $15 \mathrm{mM}$ elevated $\mathrm{K}^{+}$concentration in a clean Petri dish. Metamorphosis was defined as permanent loss of larval swimming ability due to a significant reduction or total loss of velar lobes (Pechenik \& Gee 1993). The percentage of metamorphosed larvae was recorded after $6 \mathrm{~h}$. C. onyx adults and larvae were maintained at $24^{\circ} \mathrm{C}$. Membrane filtered (pore size $0.22 \mu \mathrm{m}$ ) natural seawater (salinity $=32 \mathrm{psu}$ ) was used in all larvae rearing and experimental procedures.

Larval culture and bioassays of Hydroides elegans. Adult were collected from the intertidal zone in Port Shelter, Hong Kong (22 $19^{\prime}$ N, $\left.114^{\circ} 16^{\prime} \mathrm{E}\right)$. Calcareous tubes of adult worms were gently broken to induce spawning in Petri dishes containing $3 \mathrm{ml}$ autoclaved 
filtered seawater. All eggs from $>5$ females were pooled together and mixed with sperm from only one male in order to reduce polyspermy (Shikuma \& Hadfield 2005). Larvae were reared in filtered seawater on a diet of Isochrysis galbana. Larvae became competent and were used in bioassays on Day 5. Bioassays were carried out according to Lau et al. (2005). Briefly, 20 larvae were pipetted into each dish containing biofilms with $10 \mathrm{ml}$ autoclaved filtered seawater and incubated in still water. Autoclaved filtered seawater in a clean Petri dish served as the negative control. The positive control consisted of $10^{-4}$ M IBMX (3-isobutyl-1-methylxanthine) in autoclaved filtered seawater in a clean Petri dish. The larvae were maintained at $25^{\circ} \mathrm{C}$. Metamorphosis was defined as formation of a primary proteinacious tube and initial formation of branchial rudiments following adherence of the larva to the substratum (Shikuma \& Hadfield 2005). The percentage of metamorphosed larvae was recorded after $24 \mathrm{~h}$.

Larval culture and bioassays of Balanus amphitrite. Adult were collected from the intertidal zone in Port Shelter. Larvae at the nauplius stage were obtained from $>100$ adults and were reared to the competent stage (cyprids) on a diet of Chaetoceros gracilis Schutt (Lau et al. 2005). Newly transformed cyprids on Day 5 were used in still-water 'double-dish' choice bioassays. A 'double-dish' was constructed by connecting a biofilmed dish and a clean or another biofilmed dish into a single unit using parafilm; a unit that contained 40 to 50 larvae and $22 \mathrm{ml}$ autoclaved filtered seawater was placed vertically. The larvae were maintained at $25^{\circ} \mathrm{C}$ in the dark. A unit consisting of 2 clean dishes served as the positive control. The percentage of metamorphosed larvae was recorded after $24 \mathrm{~h}$. We used 'double-dish' bioassays with barnacle larvae because these units do not hold any air, and thus barnacle larvae would not be trapped in the air-water interface due to the surface property of the larvae themselves (Lau et al. 2005).

Statistical analysis. Percentage data were arcsinetransformed before analysis (Zar 1999). The normality of the data was checked with Shapiro-Wilk's $W$-test. Percentages of metamorphosis of Crepidula onyx and Hydroides elegans larvae and diatom and bacterial cell densities were analyzed using analysis of variance (ANOVA). Tukey's honestly significant difference (HSD) test was used to compare the means of percentage of larval metamorphosis of $C$. onyx and $H$. elegans in a pairwise manner. Percentage data of larval metamorphosis of Balanus amphitrite were analyzed using a log-likelihood replicated G-test; the null hypothesis of 1:1 ratio of the numbers of metamorphosis of the 2 dishes in a bioassay unit was tested (Zar 1999). Data among replicate bioassay units were tested for homogeneity. Homogeneous data sets were pooled and cor- responding $G$ values were transformed by Williams' correction. Data that failed to meet the homogeneity of variance criterion were analyzed non-parametrically. Untransformed data are presented in all figures.

T-RF patterns were transformed to binary character tables (1 or 0 corresponding to the presence or absence of a given T-RF in a biofilm sample) using the Genetic Profiler package (Amersham). A similarity matrix was then constructed based on the total number of T-RFs observed in all biofilm samples and the presence or absence of these T-RFs in individual samples (PRIMER, Plymouth Marine Laboratory). The similarity matrix was used to construct a non-metric multidimensional scaling (nMDS) ordination. Quantitative data were used for diatom community composition analysis and were analyzed by constructing a similarity matrix and nMDS ordination (PRIMER). Throughout this study, 2-dimensional nMDS ordinations are presented. A stress value reflects how well the 2-dimensional ordination represents the multi-dimensional distances or the 'closeness' of the community composition among the biofilm samples. The DGGE band position and intensity were manually corrected; band matching was performed with $1 \%$ position tolerance and $1 \%$ optimization using the GelCompar II package (Applied Maths). DGGE band patterns were transformed to binary character tables, and a similarity matrix and the corresponding dendrogram were then constructed. The 16S rRNA gene sequences of the DGGE bands were deposited in the GenBank with the accession numbers: EU083904-EU083907.

\section{RESULTS}

\section{Biofilm bacterial and diatom cell densities and community composition}

The mean bacterial cell densities $( \pm$ SD) of biofilms developed under nutrient enrichment and control conditions were $26640( \pm 4778)$ and $15520( \pm 5871)$ cells $\mathrm{mm}^{-2}(\mathrm{n}=5)$, respectively. While the mean diatom cell densities of biofilms developed under nutrient enrichment and control conditions were $741( \pm 71)$ and $509( \pm 61)$ cells $\mathrm{mm}^{-2}(\mathrm{n}=5)$, respectively. The nutrient enrichment treatment had a significant effect on the bacterial $(F=10.79, \mathrm{p}=0.011)$ and diatom cell densities $(F=24.60, \mathrm{p}=0.003)$.

There were 27 and 22 T-RFs present in at least 3 out of 5 replicate biofilms developed under nutrient enrichment and control conditions, respectively. Treatment-specific T-RFs were observed (Fig. 1). For example, T-RFs of 47, 177, and 422 base pairs (bp) long were only found in biofilms developed under nutrient enrichment, while T-RFs of 72, 145, and 149 bp long 


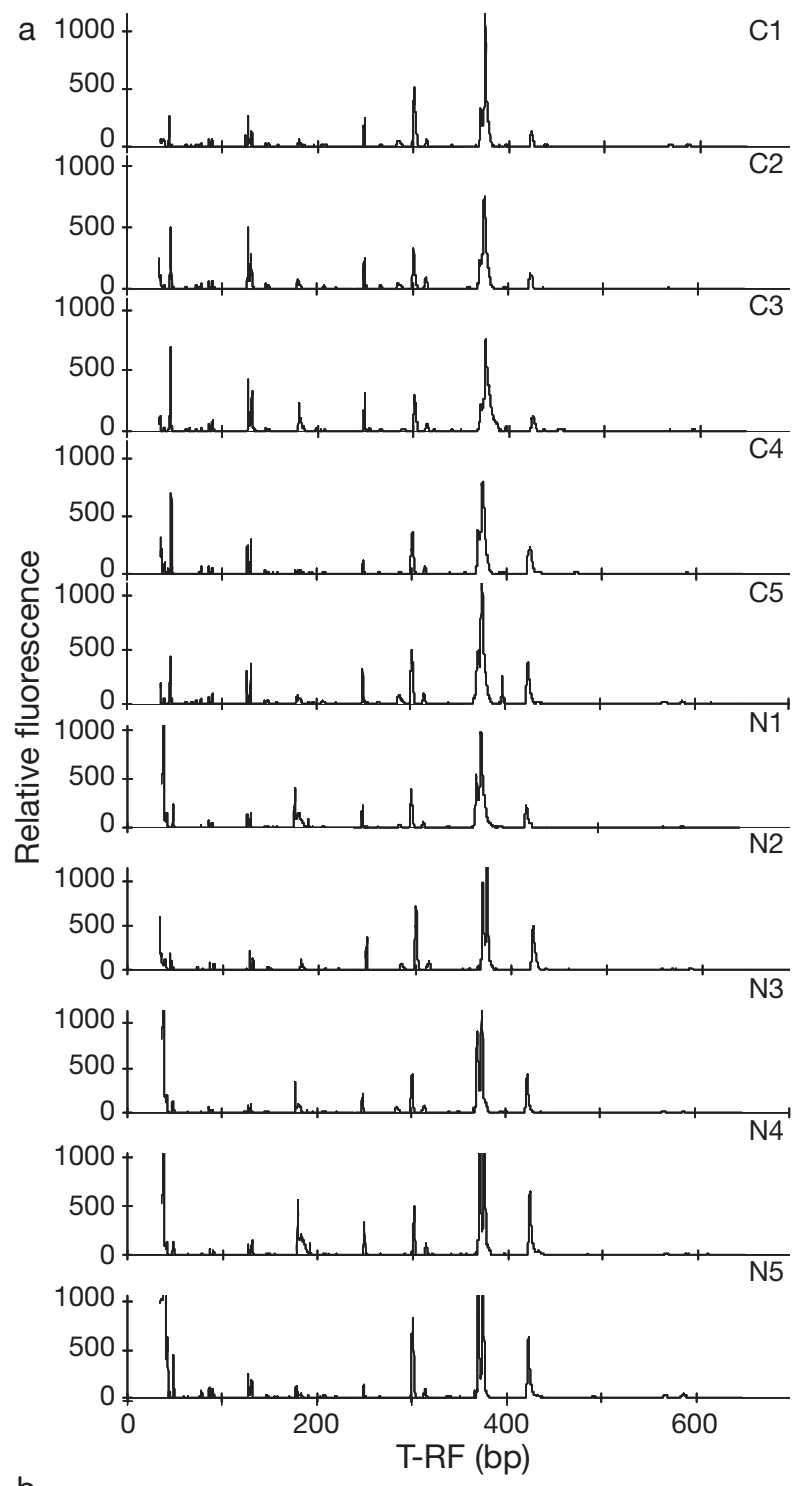

b

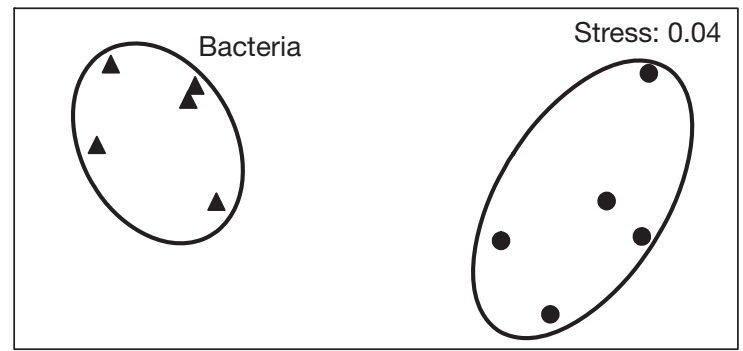

Fig. 1. (a) Terminal-restriction fragment (T-RF) length polymorphism patterns and the corresponding non-metric multidimensional scaling (nMDS) ordination comparing the bacterial community composition of biofilms developed for $10 \mathrm{~d}$ at low intertidal zones at Port Shelter under nutrient enrichment $(\boldsymbol{\Delta})$ and control conditions ( $)$. In the nMDS plot each symbol represents the result from 1 replicate biofilm sample. A stress value $<0.2$ indicates that conclusions can be drawn from the nMDS ordination with confidence. Clusters were formed at a similarity threshold of $50 \%$. C1 to C5: control conditions; N1 to N5: nutrient conditions were only found in control biofilms. The differences in biofilm bacterial community composition were indicated by the distance between the 2 groups of bacterial community composition in the nMDS plot which were also separated at a similarity threshold of $50 \%$.

Twenty-six and 20 discernible DGGE bands were present in at least 3 out of 5 replicate biofilms developed under nutrient enrichment and control conditions, respectively. Among these bands, 4 occurred exclusively in biofilms developed under nutrient enrichment, whereas 1 was unique to the control biofilms. The dendrogram constructed using the DGGE band patterns showed that the bacterial community composition in biofilms developed under nutrient enrichment and control conditions were different; they were separated at a similarity threshold of $80 \%$ (Fig. 2).

Two DGGE bands that were common to the biofilms developed under nutrient enrichment and control conditions were sequenced directly (Table 1). The closest phylogenetic affiliations for these 2 bands are Saprospira sp. isolated from Kagoshima Bay, Japan (Furusawa et al. 2003) and Pseudoalteromonas bacteriolytica isolated from red-spotted culture beds of Laminaria japonica (Sawabe et al. 1998). One unique band from biofilms developed under nutrient enrichment and one from control biofilms were cloned and sequenced. The 3 clones for the control biofilms showed high similarity (97\%) to Alteromonas sp. previously isolated from biofilms developed at Port Shelter, Hong Kong (authors' unpubl. data), while the 3 clones for the biofilms developed under nutrient enrichment all showed high similarity (96\%) to an unculturable epibiotic bacterium in squid accessory nidamental glands (Pichon et al. 2005).

Relative abundances of individual diatom taxa in biofilms developed under nutrient enrichment and control conditions were compared (Fig. 3). Nitszchia

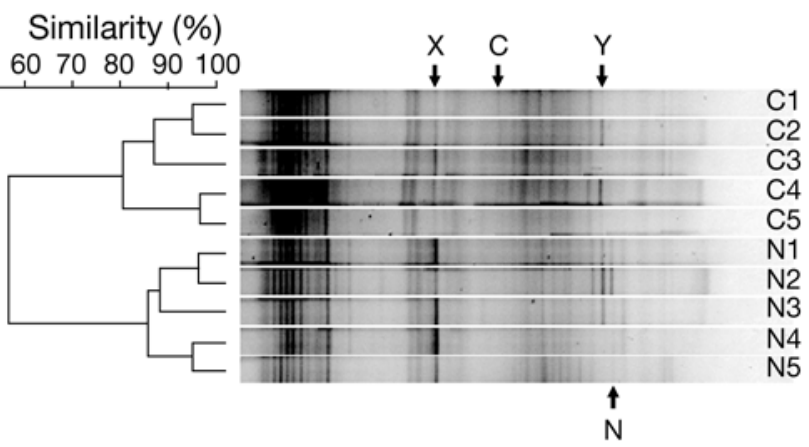

Fig. 2. DGGE profiles and the corresponding dendrogram comparing the bacterial community composition of biofilms developed under nutrient enrichment (N1 to N5) and control conditions ( $\mathrm{C} 1$ to $\mathrm{C} 5$ ). Two clusters were formed at a similarity threshold of $80 \%$. Labeled bands were sequenced (see Table 1). X, Y: common DGGE bands. C: unique DGGE band under control conditions; N: unique DGGE band under nutrient conditions 
Table 1. Phylogenetic affiliations of common DGGE bands (X and Y) or unique bands found in control biofilms (C) and biofilms developed under nutrient enrichment $(\mathrm{N})$ (see Fig. 2). Bands were exercised, reamplified, and directly sequenced (X and Y), or cloned and sequenced (C and N). Partial 16S rRNA gene sequences of the DGGE bands were compared against the nucleotide sequences deposited in GenBank

\begin{tabular}{|c|c|c|c|}
\hline $\begin{array}{l}\text { DGGE } \\
\text { band }\end{array}$ & $\begin{array}{l}\text { Closest affiliation } \\
\text { (accession no.) }\end{array}$ & $\begin{array}{l}\text { Phylogenetic } \\
\text { group }\end{array}$ & $\underset{(\%)}{\text { Similarity }}$ \\
\hline $\mathrm{C}$ & $\begin{array}{l}\text { Alteromonas sp. from Hong Kong } \\
\text { Port Shelter biofilms (EF588004) }\end{array}$ & $\gamma-$ Proteobacteria & 97 \\
\hline $\mathrm{N}$ & $\begin{array}{l}\text { Uncult. epibiotic bacterium in } \\
\text { squid accessory nidamental } \\
\text { glands (AJ633964) }\end{array}$ & $\alpha-$ Proteobacteria & 96 \\
\hline $\mathrm{X}$ & $\begin{array}{l}\text { Saprospira sp. from } \\
\text { Kagoshima Bay (AB088635) }\end{array}$ & Bacteroidetes & 98 \\
\hline $\mathrm{Y}$ & $\begin{array}{l}\text { Pseudoalteromonas bacteriolytica } \\
\text { from red-spotted culture beds of } \\
\text { Laminaria japonica (D89929) }\end{array}$ & $\gamma$-Proteobacteria & 99 \\
\hline
\end{tabular}

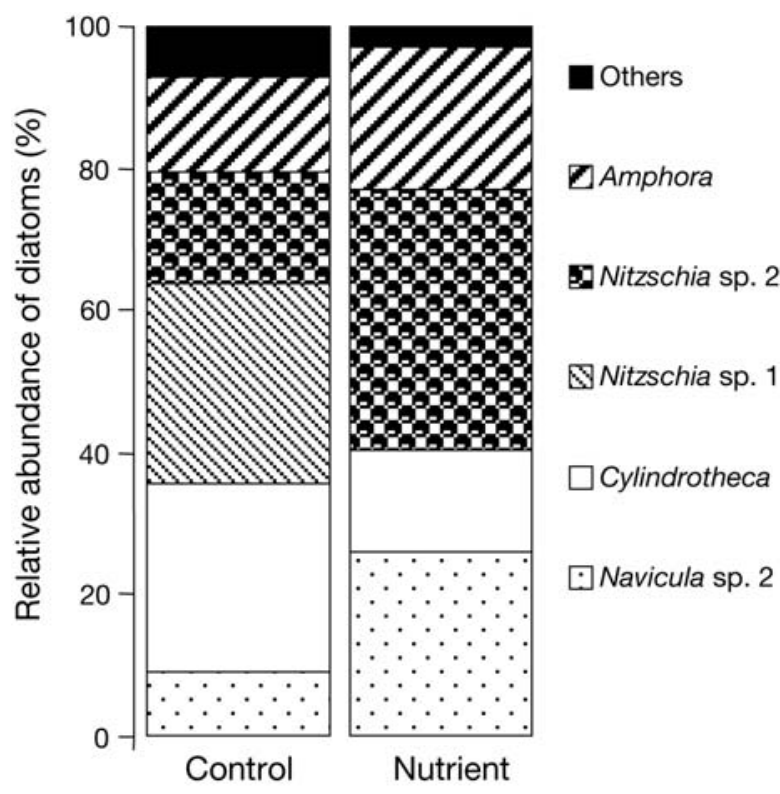

Fig. 3. Relative abundance of different diatoms in biofilms developed under nutrient enrichment and control conditions. The data for each treatment show the mean result from 5 biofilmed dishes

sp. 1 and Cylindrotheca spp. were the most dominant diatom taxa in control biofilms, but were replaced by Nitszchia sp. 2 and Navicula sp. 2 in biofilms developed under nutrient enrichment. Differences in diatom community composition between biofilms developed under nutrient enrichment and control conditions were visualized using nMDS plot (Fig. 4). The 2 groups of diatom community composition were separated at a similarity threshold of $60 \%$.

\section{Larval metamorphosis}

An average of $92 \%$ of Crepidula onyx larvae metamorphosed in the presence of excess $\mathrm{K}^{+}$within $6 \mathrm{~h}$, whereas only $22 \%$ of the larvae metamorphosed in the negative control (autoclaved filtered seawater and a clean surface) in the same time period (Fig. 5). Therefore, most larvae were competent to metamorphose at the start of the experiments, and most of the metamorphosis that occurred in the experimental treatments was caused by the presence of biofilms. The biofilms that developed under nutrient enrichment caused significantly higher percentages of larvae to metamorphose relative to that of their control counterparts $(\mathrm{p}<0.001$, Tukey's HSD test).

Hydroides elegans larval metamorphosis in the negative control averaged $1 \%$ (Fig. 6). Therefore, most of the metamorphosis that occurred in the experimental treatments was very likely caused by the presence of biofilms. Exposing larvae to biofilms caused significantly higher percentages of larvae to metamorphose than that of the negative control ( $\mathrm{p}<0.001$, Tukey's test). Moreover, mean percentage metamorphosis of larvae exposed to the biofilms that developed under nutrient enrichment and those under control conditions did not differ significantly $(p=0.719$, Tukey's test).

In the 'double-dish' metamorphosis bioassays of Balanus amphitrite larvae, the larvae metamorphosed with equal number on the 2 sides in the positive control

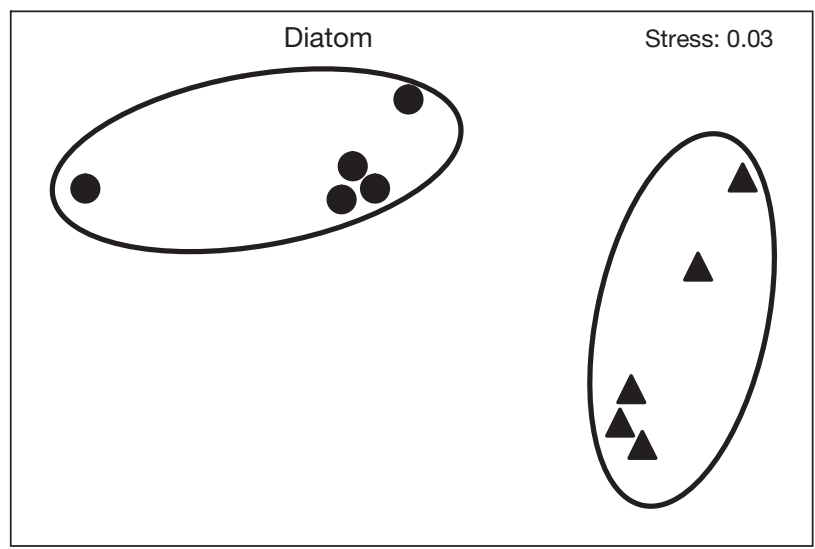

Fig. 4. Non-metric multidimensional scaling (nMDS) ordination comparing the diatom community composition of biofilms developed under nutrient enrichment $(\boldsymbol{\Lambda})$ and control conditions $(\mathbf{O})$. A stress value $<0.2$ indicates that conclusions can be drawn from the nMDS ordination with confidence. Clusters were formed at a similarity threshold of $60 \%$ 


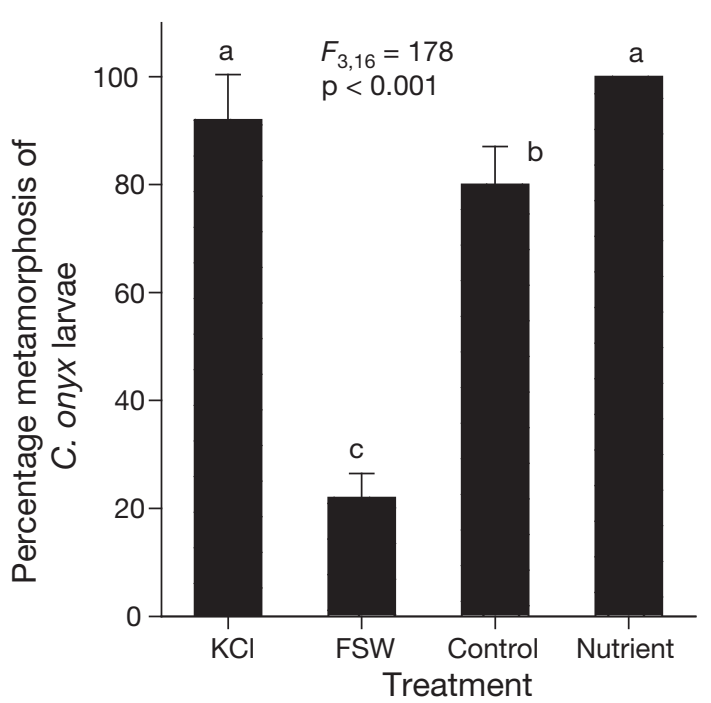

Fig. 5. Crepidula onyx. Effects of biofilms developed under nutrient enrichment on larval metamorphosis. Percentage metamorphosis was determined after $6 \mathrm{~h}$ at $24^{\circ} \mathrm{C}_{\text {i }}$ each bar represents the mean \pm SD from 5 biofilmed dishes, with 10 larvae each. Biofilmed dishes were developed under nutrient enrichment (Nutrient) or control conditions (Control). Autoclaved filtered seawater (FSW) in a clean Petri dish served as the negative control. The positive control consisted of seawater with a $15 \mathrm{mM}$ elevated $\mathrm{K}^{+}$concentration in a clean Petri dish $(\mathrm{KCl})$. One-way ANOVA results are shown. Means that are significantly different in Tukey's HSD test are indicated by different letters

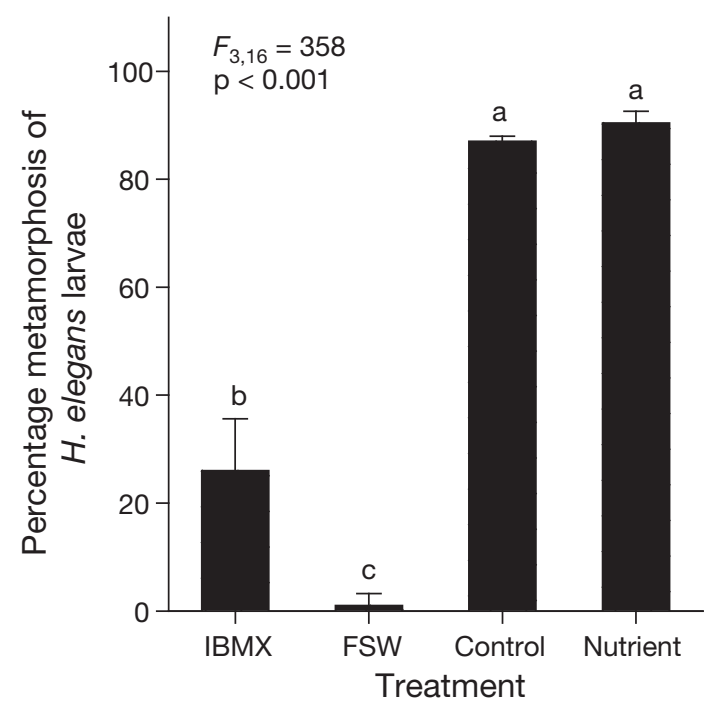

Fig. 6. Hydroides elegans. Effects of biofilms developed under nutrient enrichment on larval metamorphosis. Percentage metamorphosis was determined after $24 \mathrm{~h}$ at $25^{\circ} \mathrm{C}_{i}$ each bar represents the mean \pm SD result from 5 biofilmed dishes, with 20 larvae each. The positive control consisted of $10^{-4} \mathrm{M}$ IBMX (3-isobutyl-1-methyl-xanthine) in autoclaved filtered seawater (FSW) in a clean Petri dish. One-way ANOVA results are shown. Means that are significantly different in Tukey's HSD test are indicated by different letters

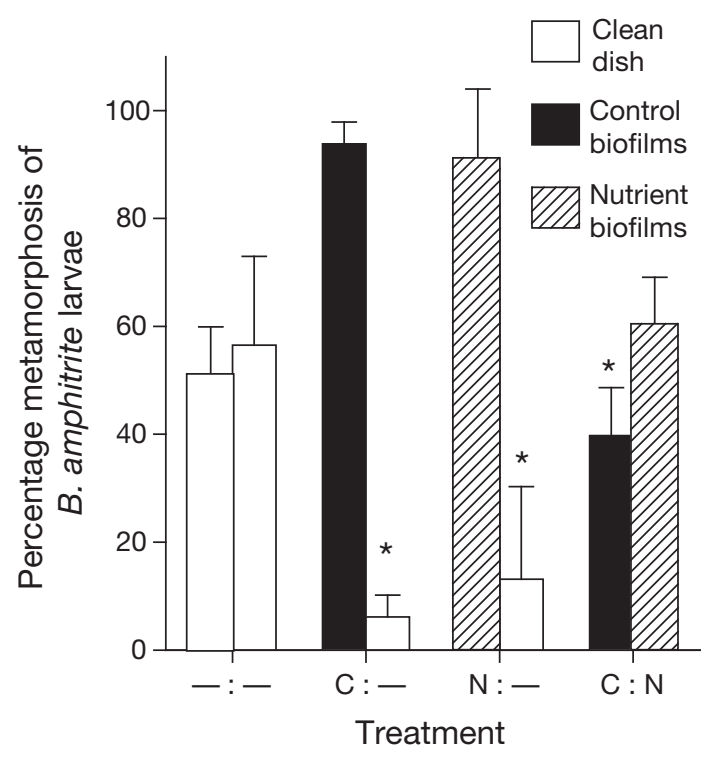

Fig. 7. Balanus amphitrite. Effects of biofilms developed under nutrient enrichment $(\mathrm{N})$ or control $(\mathrm{C})$ conditions on larval metamorphosis in 'double-dish' bioassays. —: clean dish. A 'double-dish' was constructed by connecting a biofilmed dish and a clean dish $(\mathrm{C}:-, \mathrm{N}:-)$ or 2 biofilmed dishes $(\mathrm{C}: \mathrm{N})$ into a single unit. Two clean dishes (-:-) served as the positive control. Percentage metamorphosis was determined after $24 \mathrm{~h}$ at $25^{\circ} \mathrm{C}$; each pair of bars represents the mean $\pm \mathrm{SD}$ results from 5 units, with 40 to 50 larvae each. * : ratio of the numbers of metamorphosis of the 2 dishes in a unit that deviated from the expected $1: 1$ ratio $(p<0.05, \log$-likelihood test $)$

(Fig. 7). In contrast, when larvae were exposed to a biofilmed dish and a clean dish at the same time, they metamorphosed with a higher number on the biofilmed than on the clean side (biofilms developed under nutrient enrichment: $G=67.17$, p < 0.001; control biofilms: $G=88.85$, p < 0.001). Furthermore, when larvae were exposed to a unit consisting of biofilms developed under nutrient enrichment and control biofilms, they metamorphosed with a higher number on the nutrient-enriched biofilms than on control biofilms $(G=4.54$, p < 0.05).

\section{DISCUSSION}

The 2 DNA fingerprinting techniques T-RFLP (Fig. 1) and DGGE (Fig. 2) demonstrated a shift in the bacterial community composition as a result of nutrient enrichment in the water column during biofilm development. T-RFLP analysis distinguished the bacterial community of biofilms developed under nutrient enrichment from that of control biofilms that were separated at a similarity threshold of $50 \%$, while DGGE analysis also distinguished the 2 types of bacterial community at a similarity threshold of $80 \%$. The 2 
techniques give different similarity thresholds as a result of different DNA separation mechanisms being employed. T-RFLP reveals sequence heterogeneity in the 16S rRNA genes by sequence specific enzymatic digestion of PCR amplicons, while DGGE reveals sequence heterogeneity according to the denaturation behaviors of double-stranded DNA of different $\mathrm{G}+\mathrm{C}$ contents. Despite the known biases and limitations inherent to each method, we could reach a presumably more reliable description of bacterial community composition through concomitant application of T-RFLP and DGGE on the same samples (Hoffmann et al. 2002).

It has been established for marine, limnetic, and brackish habitats that the bacterial communities of water columns and of sediments are responsive to ambient nutrients (e.g. Araya et al. 2003, Horner-Devine et al. 2003). However, little was known about the impacts of nutrients on the bacterial communities in marine intertidal biofilms before the present study, which showed that nutrient enrichment increased the density and shifted the composition of bacteria in biofilms. The shift in bacterial composition could be a result of altered outcomes of competitive interactions between individual species differing in their uptake, storage, and assimilation kinetics, and thus selective advantages at different nutrient levels (Suttle et al. 1987). While the effects of inorganic nutrients on autotrophic bacteria are direct and obvious (growth stimulatory), their effects on heterotrophic bacteria can be mediated through the exudates of autotrophic components including diatoms and cyanobacteria (reviewed by Horner-Devine et al. 2003). The dense diatoms found in the biofilms could constitute areas of favorable organic nutrient conditions to the heterotrophic bacteria. Saprospira sp., which was the closest affiliation of a DGGE band found in biofilms developed under nutrient enrichment and control conditions, was able to kill and lyse diatom cells (Furusawa et al. 2003). Furthermore, how bacterial communities in biofilms react to nutrients may be slightly different from those in the plankton. Whether or not bacteria adhere to a substratum may be determined by nutrients, and such behaviors may affect the biofilm bacterial communities, yet studies on this aspect have generally been performed using artificial biofilm models (reviewed by Araya et al. 2003).

Nutrient enrichment in the water column changed the biofilm composition in ways that increased its inductiveness for larval metamorphosis of Crepidula onyx (Fig. 5). C. onyx larvae were previously shown to be sensitive to differences in bacterial and diatom community composition (Chiu et al. 2007). Given the fact that nutrient enrichment altered the bacterial (Fig. 2) and diatom (Fig. 3) community composition, it was likely that $C$. onyx larvae responded differently to the biofilms developed under nutrient enrichment compared to the control biofilms. Similarly, Balanus amphitrite larvae preferred the biofilms developed under nutrient enrichment to the control biofilms as illustrated in the 'double-dish' metamorphosis bioassays (Fig. 7). It was suggested that metamorphosis of barnacle larvae was determined by the bacterial community (Qian et al. 2003, Lau et al. 2005), but bacterial density or diatoms may play a role in metamorphosis since different bacterial cell densities were found in the 2 biofilms and $B$. amphitrite larvae can respond to merely the diatom components of biofilms (e.g. Miron et al. 1999). Although the biofilm attributes to which the $B$. amphitrite larvae responded were not reported here, it was clear that nutrient enrichment increased the inductiveness of biofilms for $B$. amphitrite larval metamorphosis.

In contrast to Crepidula onyx and Balanus amphitrite larvae, Hydroides elegans larvae did not discriminate among the biofilms developed under nutrient enrichment and control conditions that had different bacterial community composition (Fig 6). Biofilms, either of natural multispecies or monospecies origin, are a prerequisite for larval metamorphosis of $H$. elegans (Shikuma \& Hadfield 2005). In agreement with the results here, Lau et al. (2005) showed that $H$. elegans larvae did not respond differently to natural multispecies biofilms harboring different bacterial communities. However, other studies have generally concluded that bacterial species composition could influence larval metamorphosis based on the observation that monospecies biofilms of different bacterial species induced different levels of metamorphosis (e.g. Huang \& Hadfield 2003). If bacterial species composition does indeed influence larval metamorphosis, the lack of effect of nutrient enrichment on $H$. elegans metamorphosis in this study could be due to the fact that changes in bacterial community composition driven by nutrient enrichment did not include the specific bacterial species essential for metamorphosis of $H$. elegans.

Balanus amphitrite larvae have been hypothesized to distinguish biofilms originating from habitats that support higher recruitment as well as juvenile growth and survival (e.g. Lau et al. 2005). In this study, B. amphitrite and Crepidula onyx larvae exhibited high metamorphic rates on the biofilms developed under nutrient enrichment. While nutrient levels are closely linked to phytoplankton and hence food abundance, our findings here further support the hypothesis that biofilms serve as important signposts for B. amphitrite and $C$. onyx larvae seeking suitable substrata for subsequent juvenile growth and survival. Nutrients may also be indicative of stable benthic assemblages, 
as in other invertebrate species nutrients are released by conspecific adults and serve as cues that induce larval metamorphosis (Fitt \& Coon 1992). Support for this hypothesis for $B$. amphitrite and C. onyx awaits future experiments. In contrast, Hydroides elegans is the primary colonizer of newly submerged surfaces in the succession of macrofouling invertebrates. If the strategy is to colonize a wider range of habitats faster, larvae may have a less stringent choice of substrata. Therefore, larval metamorphosis of $H$. elegans was not affected by nutrients but rather, as demonstrated in other studies, by the age of biofilms, which indicates the likelihood that the surface will be submerged long enough for the animal to mature and reproduce (reviewed by Shikuma \& Hadfield 2005).

The present study highlights the apparent importance of nutrient enrichment in influencing the intertidal biofilm composition directly and the invertebrates indirectly. The composition of a community is largely affected by the recruitment of new individuals into the population (Underwood \& Keough 2001). The recruitment process of marine benthic invertebrates is a result of a combination of processes including dispersal of larvae in the plankton, larval metamorphosis, and growth and survival of young juveniles. The slipper limpet Crepidula onyx and the barnacle Balanus amphitrite are dominant species of the intertidal zone on rocky shorelines in tropical and sub-tropical regions. If nutrient enrichment affects larval metamorphosis and hence recruitment, the composition of populations in intertidal communities is likely to be affected significantly. To extend this work, future studies may consider longterm in situ observations of intertidal communities including algal growth and production and the concomitant change in abundance and biomass of invertebrate populations in response to increasing nutrient loads. Knowledge of the interactive effects of nutrient levels and biotic factors such as predation and competition on benthic systems is also critical if we are to predict the outcomes of nutrient enrichment on marine ecosystems including range-shifts and changes in abundance of key ecosystem-structuring species.

Acknowledgements. This manuscript benefited greatly from the comments and suggestions of 3 anonymous reviewers. We thank J. A. Pechenik (Tufts University) for providing the fertilizers used in this study. We are also grateful to S. C. K. Lau and K. Tam for editorial and technical help. This study was supported by the Area of Excellence Scheme of UGC (Project no. AoE/P-04/2004) and RGC grants (HKUST 6402/05M) to P.Y.Q. and the AMCE Program's Postgraduate Studentship to J.M.Y.C.

\section{LITERATURE CITED}

Araya R, Tani K, Takagi T, Yamaguchi N, Nasu M (2003) Bacterial activity and community composition in stream water and biofilm from an urban river determined by fluorescent in situ hybridization and DGGE analysis. FEMS Microbiol Ecol 43:111-119

Bassim KM, Sammarco PW (2003) Effects of temperature and ammonium on larval development and survivorship in a scleractinian coral (Diploria strigosa). Mar Biol 142: 241-252

Chiu JMY, Thiyagarajan V, Pechenik JA, Hung OS, Qian PY (2007) Influence of bacteria and diatoms in biofilms on metamorphosis of the marine slipper limpet Crepidula onyx. Mar Biol 151:1417-1431

Fitt WK, Coon SL (1992) Evidence for ammonia as a natural cue for recruitment of oyster larvae to oyster beds in a Georgia salt marsh. Biol Bull 182:401-408

Forward RB, Tankersley RA, Blondel D, Rittschof D (1997) Metamorphosis of the blue crab Callinectes sapidus: effects of humic acids and ammonium. Mar Ecol Prog Ser 157:277-286

Furusawa G, Yoshikawa T, Yasuda A, Sakata T (2003) Algicidal activity and gliding motility of Saprospira sp. SS98-5. Can J Microbiol 49:92-100

Hoffmann T, Horz HP, Kemnitz D, Conrad R (2002) Diversity of the particulate methane monooyxgenase gene in methanotrophic samples from different rice field soils in China and the Philippines. Syst Appl Microbiol 25: $267-274$

Horner-Devine MC, Leibold MA, Smith VH, Bohannan BJM (2003) Bacterial diversity patterns along a gradient of primary productivity. Ecol Lett 6:613-622

Huang SH, Hadfield MG (2003) Composition and density of bacterial biofilms determine larval settlement of the polychaete Hydroides elegans. Mar Ecol Prog Ser 260:161-172

Lau SCK, Thiyagarajan V, Cheung SCK, Qian PY (2005) A laboratory investigation of the role of bacterial community in biofilm as an indicator of local environmental conditions for the settling larvae of marine invertebrates. Aquat Microb Ecol 38:41-51

Lee JHW, Harrison PJ, Kuang C, Yin K (2006) Eutrophication dynamics in Hong Kong coastal waters: physical and biological interactions. In: Wolanski E (ed) The environment in Asia Pacific harbours. Springer, Dordrecht, p 187-206

Liu WT, Marsh TL, Cheng H, Forney LJ (1997) Characterization of microbial diversity by determining terminal restriction fragment length polymorphisms of genes encoding 16S rRNA. Appl Environ Microbiol 63:4516-4522

Minchinton TE, Bertness MD (2003) Disturbance-mediated competition and the spread of Phragmites australis in a coastal marsh. Ecol Appl 13:1400-1416

Miron G, Boudreau B, Bourget E (1999) Intertidal barnacle distribution: a case study using a multiple working hypothesis. Mar Ecol Prog Ser 189:205-219

Morris L, Keough MJ (2003) Variation in the response of intertidal infaunal invertebrates to nutrient additions: field manipulations at two sites within Port Phillip Bay, Australia. Mar Ecol Prog Ser 250:35-49

Pechenik JA, Gee CC (1993) Onset of metamorphic competence in larvae of the gastropod Crepidula fornicata (L.), judged by a natural and an artificial cue. J Exp Mar Biol Ecol 167:59-72

Pechenik JA, Jarrett JN, Rooney J (2002) Relationships between larval nutritional experience, larval growth rates, juvenile growth rates, and juvenile feeding rates in the prosobranch gastropod Crepidula fornicata. J Exp Mar Biol Ecol 280:63-78

Pichon D, Gaia V, Norman MD, Boucher-Rodoni R (2005) Phylogenetic diversity of epibiotic bacteria in the accessory nidamental glands of squids (Cephalopoda: Loliginidae 
and Idiosepiidae). Mar Biol 147:1323-1332

Qian PY, Thiyagarajan V, Lau SCK, Cheung SCK (2003) Relationship between bacterial community profile in biofilm and attachment of the acorn barnacle Balanus amphitrite. Aquat Microb Ecol 33:225-237

Sawabe T, Makino H, Tatsumi M, Nakano K and others (1998) Pseudoalteromonas bacteriolytica sp. nov., a marine bacterium that is the causative agent of red spot disease of Laminaria japonica. Int J Syst Bacteriol 48:769-774

Shikuma NJ, Hadfield MG (2005) Temporal variation of an initial marine biofilm community and its effects on larval settlement and metamorphosis of the tubeworm Hydroides elegans. Biofilms 2:231-238

Suttle CA, Stockner J, Harrison PJ (1987) Effects of nutrient pulses on community structure and cell size of a freshwater phytoplankton assemblage in culture. Can J Fish Aquat Sci 44:1768-1774

Editorial responsibility: Otto Kinne, Oldendorf/Luhe, Germany
Tomas CR (ed) (1996) Identifying marine diatoms and dinoflagellates. Academic Press, San Diego, CA

Toonen RT, Pawlik JR (1994) Foundations of gregariousness. Nature 370:511-512

Underwood AJ, Keough MJ (2001) Supply-side ecology: the nature and consequences of variations in recruitment of intertidal organisms. In: Bertness MD, Gaines SD, Hay ME (eds) Marine community ecology. Sinauer Associates, Sunderland, MA, p 183-200

Wieczorek SK, Todd CD (1998) Inhibition and facilitation of settlement of epifaunal marine invertebrate larvae by microbial biofilm cues. Biofouling 12:81-118

Worm B, Reusch TBH, Lotze HK (2000) In situ nutrient enrichment: methods for marine benthic ecology. Int Rev Hydrobiol 85:359-375

Zar JH (1999) Biostatistical analysis, 4th edn. Prentice Hall, Englewood Cliffs, NJ

Submitted: August 14, 2007; Accepted: October 29, 2007 Proofs received from author(s): April 2, 2008 